\title{
Piotr Bogalecki
} http://orcid.org/0000-0002-6227-9765

Uniwersytet Śląski w Katowicach

\section{Błogosławieństwa awangardy. „Pisarz pism nie św.” Miron Białoszewski ${ }^{1}$}

\section{Abstract \\ Blessings of Avant-Garde. "The Scribe of (Un)Holy Scriptures" Miron Białoszewski}

It can be observed that the hitherto prevailing tendencies of reading Miron Białoszewski's works - saturated with religious references used in an idiomatic or profane way - have been either metaphysical (A. and T. Sobolewski, M. Stala, A. Zagajewski) or linguistic (J. Sławiński, E. Balcerzan, S. Barańczak). These two extremities produce a gap that can be bridged by a reading which combines the postsecular perspective, understood in an institutional way, with neo-avant-garde (in H. Foster's interpretation). Just as the avant-garde is a critique of the obligatory art institution (P. Bürger), so can postsecularism be understood as a critique of the current institution of religion. The article presents readings of Kalejdoskop (Kaleidoscope) and of poems written in the 1950s and 1960s, and shows Białoszewski's poetry as neo-avant-garde and postsecular at the same time, depicting the writer as the first postwar postsecular Polish poet.

Słowa kluczowe: Miron Białoszewski, postsekularyzm, poezja postsekularna, awangarda, neoawangarda, epifania, literatura i religia

Keywords: Miron Białoszewski, postsecularism, postsecular poetry, avant-garde, neoavant-garde, epiphany, literature and religion

1 Artykuł powstał w ramach projektu badawczego „Literatura a religia - wyzwania epoki świeckiej” (NPRH0052/NPRH4/2a/83/2016). 
na odpust poezji

na nieustanne uroczyste zdziwienie...!

(O mojej pustelni z nawoływaniem, I, $70^{2}$ )

\section{Mistrz, mistyk, mistyfikator. Białoszewski i czytelnicy}

Choć trudno przypuszczać, by autor Mylnych wzruszeń uznany mógł zostać za poetę religijnego, zastanawiać może, skąd aż tyle odniesień do religii w tekstach jego autorstwa i tekstach mu poświęconych. Powody, dla których czytelnicy Białoszewskiego uciekają się pod obronę tego, co religijne, wydają się mieć charakter tyleż literaturoznawczy, ile, by tak rzec, półprywatny. W znacznej części poświęconych mu opracowań przywoływana jest wszak legenda człowieka imieniem Miron, będącego dla wielu, jak ujmuje to Anna Sobolewska, kimś w rodzaju „mistrza duchowego” oraz „nauczyciela poetyckiej kontemplacji świata i wolności wewnętrznej”3. Przypominając to stwierdzenie oraz inne podobne wypowiedzi osób z bliskiego kręgu poety ${ }^{4}$, Adam Poprawa podkreślał jakiś czas temu ich wpływ na kształtowanie się „od dawna istotnego i wciąż powiększanego działu badawczej recepcji Białoszewskiego", jaki stanowić miałaby „mironologia głębinowa, czyli interpretowanie utworów autora Szumów, zlepów, ciagów jako tekstów metafizycznych, egzystencjalnych, filozoficznych, religijnych..." `. Szczególnie często przytaczane są w tym kontekście powstające od lat osiemdziesiątych teksty małżeństwa Anny i Tadeu-

2 Cytując fragmenty tekstów Mirona Białoszewskiego, odsyłam do wydawanych przez Polski Instytut Wydawniczy Utworów zebranych (Warszawa 1987-2017); cyfra rzymska oznacza tom, arabska zaś numer strony. Cytaty pochodzące z Tajnego dziennika (Kraków 2012) przytaczam z podaniem skrótu TD i numerem strony.

3 A. Sobolewska, Mapy duchowe wspótczesności. Co nam zostało z Nowej Ery?, Warszawa 2009, s. 345.

4 Ich najpełniejszy wybór przynosi książka Miron. Wspomnienia o poecie, poświęcona - jak powiada na wstępie Hanna Kircher - ,istnieniu, które było życio-poezją i zwało się Miron”, obcowanie zaś z nim było dla jej autorów „uczestnictwem w zbiorowym święcie, w improwizowanym spektaklu, w obrzędach szczególnej magii, ludycznej i poetyckiej zarazem" (H. Kircher, Człowiek-Miron. Zamiast wstępu [w:] Miron. Wspomnienia o poecie, oprac. H. Kircher, Warszawa 1996, s. 9).

5 A. Poprawa, Mistrz duchowy w trafach społecznych [w:] Białoszewski przed „Dziennikiem”, red. W. Browarny, A. Poprawa, Kraków 2010, s. 147. O rozległości tego wpływu dobrze świadczy fakt, że gdy w swoim słynnym eseju Przeciw poezji niezrozumiatej Czesław Miłosz przedstawił autora Oho jako „najbardziej może wschodniego z polskich poetów”, dopowiedział, że wschodniość ta „łączyła się u niego z pewnym stylem życia, zastanawiającym tych, którzy go znali: niedbałość o własną osobę, stosunek oderwania, prawie doskonałego buddyjskiego mnicha” (C. Miłosz, Przeciw poezji niezrozumiałej, „Teksty Drugie" 1990, nr 5-6, s. 161). 
sza Sobolewskich. W opublikowanej w 1997 roku książce tej pierwszej obok nieznanych wcześniej anegdot, historycznych uściśleń oraz bardziej lub mniej przekonujących, lecz zawsze śmiałych i inspirujących propozycji interpretacyjnych pojawia się następujące wyznanie:

Należąc do jego „wiernych”, nie jego ubóstwialiśmy, ale rzeczywistość zobaczoną za jego pośrednictwem. Jego więź z rzeczywistością i silne poczucie własnego $j a$ miały niezwykły charakter. Tym religijnym w istocie poczuciem kontaktu z rzeczywistością obdarzał swoich przyjaciół i wszystkich napotkanych ludzi ${ }^{6}$.

W Maksymalnie udanej egzystencji wyznania tego typu nie tylko współkreują literacką legendę Mistrza Mirona, ale także wzmacniają wymowę przedstawianych tam literaturoznawczych rozpoznań. A zatem stawiając tezę, że ,wiele jego wierszy kryje w sobie wzór spirali”, dodawała Sobolewska na marginesie wiersza Poruszenie:

Białoszewski przekonywał mnie kiedyś, że jak wpatrzyć się w oborską wierzbę, zbliżając się do niej szybkim, jednostajnym krokiem - drzewo się obraca, a z nim cały kosmos. W każdym punkcie znajduje się bowiem oś ruchu, centrum wszechświata ${ }^{7}$.

Z kolei nośnej propozycji powiązania go z zen (,,Sposób patrzenia Mirona Białoszewskiego na świat to właśnie zen") towarzyszyła pochwała kontemplacyjnego spojrzenia poety, mieszczącego w sobie „uwagę, współczucie i rozumienie” i pozwalającego „otworzyć się na świat, odnaleźć wewnętrzność rzeczy, »dobry styk z wiecznością«". Wreszcie stwierdzając, że „wobec życiowych przeciwności i napięć radził poeta przyjąć postawę »świętej obojętności«, wypracowaną przez mnichów Wschodu i Zachodu (zalecaną między innymi przez świętego Franciszka Salezego)", dodawała badaczka, że był przy tym Białoszewski ,najżyczliwszym, najbardziej wyrozumiałym i wielkodusznym człowiekiem, jakiego znaliśmy" ". Podobnymi tonami wybrzmiewają liczne fragmenty pochodzącej z 2012 roku biografii Człowiek Miron Tadeusza Sobolewskiego - na przykład nieomal hagiograficzne wyliczenie religijnych pasji poety:

${ }^{6}$ A. Sobolewska, Maksymalnie udana egzystencja. Szkice o życiu i twórczości Mirona Białoszewskiego, Warszawa 1997, s. 15.

7 Ibidem, s. 57, 59.

8 Ibidem, s. 93, 59.

9 Ibidem, s. 16-17. 
Był zadomowiony w Biblii, w historii Chrystusa, mistyków, świętych. Poprzez Leszka [Solińskiego - dop. P.B.] zaprzyjaźnił się z franciszkankami służebnicami Krzyża z klasztoru na Piwnej i z Lasek. Wzorem poezji od dzieciństwa były dla niego kościelne nieszpory [...]. Podziwiał psalmy, które na swoim religijnym, mistycznym rusztowaniu przenosiły konkret życia. Od dzieciństwa [...] obserwował liturgię i uczestniczył w niej (jedną z jego ulubionych zabaw była procesja - miał zbiór malutkich chorągwi wyciętych z glansowanego papieru, które kiedyś pogryzły mu myszy) ${ }^{10}$.

Nie poprzestając na odnotowaniu - zadziwiająco licznych - religijnych i parareligijnych ${ }^{11}$ zainteresowań poety, dowodzi badacz, że fascynacji tej nie porzucał Białoszewski, pochylając się nad kartką papieru: ,w swoim pisaniu naśladował tok liturgicznej mowy, litanii, psalmu, uświęcając to, co materialne, własne, »sprawdzone sobą«, zakurzone jak kościelne figury w Starej pieśni na Binnarowa" ${ }^{\prime 2}$. Nie tylko z tekstów wczesnych, ale i z późnych Odmian łapań tchu wyłania się zatem obraz autora, w którego ,»niewierzących« wierszach i prozach Bóg, aniołowie, Chrystus, święci, mistycy przywoływani są nieustannie, bezceremonialnie, jak postacie literatury" ${ }^{\prime 3}$. Niezależnie bowiem od biograficznych wzmocnien, to przede wszystkim teksty autora Obrotów rzeczy uprawniają Sobolewskiego do uznania jego twórczości za „prywatną teologię”, postawy twórczej - za ,nieustanną kontemplację istnienia”, pisania - za „liturgię i formę miłości”, wreszcie zaś „spokój, może nicość” jego tekstów - za „obietnicę zbawienia"14. Rzecz jasna, pod adresem takich z założenia nieostrych sformułowań zgłaszać można rozmaite zastrzeżenia; można też jednak uznać, że gra toczy się w nich nie tyle o precyzję, ile o wyznaczenie kierunku, w którym zmierzała znacząca część omawianej twórczości -

10 T. Sobolewski, Człowiek Miron, Kraków 2014, s. 201.

11 Ich istnienie odnotowywała wcześniej m.in. Jadwiga Stańczakowa, pisząca o „Mironie, którego pasjonowały zjawiska parapsychiczne”, do którego „ulubionych książek” należały te „z zakresu parapsychologii” i który „we wczesnej młodości miał duże zdolności parapsychiczne, np. umiał poruszać przedmioty siłą woli” (J. Stańczakowa, Ocalić wszystko [w:] Pisanie Białoszewskiego. Szkice, red. M. Głowiński, Z. Łapiński, Warszawa 1993, s. 262). W Tajnym dzienniku o zjawiskach takich pisze poeta raczej z dystansem (np. we fragmencie rozpoczynającym się od słów „Od pewnego czasu modne są w Polsce medytacje”); poważniej wypowiada się natomiast o rzymskokatolickiej liturgii, dystansując się od powstającego na jego oczach posoborowego „kościoła ciemnego”, a szczególną atencją darząc ten przedsoborowy: „Teraz, kiedy Kościół zmienia u siebie tyle rzeczy, kiedy idą w odstawkę stare tłumaczenia, uświęcone pokoleniami sformułowania, słowa, nazwy, wreszcie łacina, śpiewy gregoriańskie, może się porwać cała misterna sieć kultury i łączności ludzi ze sobą poprzez wieki. Powinni wdać się w to wierzący i niewierzący. Cała Europa" (TD, s. 560, 315, 141-142).

12 T. Sobolewski, Człowiek Miron, s. 201.

13 Ibidem, s. 79.

14 Ibidem, s. 75, 77, 108. 
i w którym podążać powinny jej odczytania. Nieco tylko uogólniając, powiedzieć można zatem, że dla Sobolewskiego pisarstwo autora Rozkurzu stanowiło rodzaj zasadniczo świeckiego, acz niepozbawionego zainteresowania metafizyką, ekwiwalentu postawy religijnej: „,udało mu się w pisaniu znaleźć ten model odbicia, jaki dla wierzącego stwarza religia"15.

W podobny sposób twórczość tę postrzegało i obecnie postrzega wielu jej badaczy, przy czym wspomniany „ekwiwalent” zyskuje w ich tekstach odmienne imiona, zależne od analizowanych utworów czy przywoływanych kontekstów. Jeżeli we wspomnieniach Sobolewskiego bywał Białoszewski „kapłanem”, „magiem” i „,szamanem”, „spełniającym wśród ludzi ze swego otoczenia jakąs archaiczną funkcję"16, to określającemu jego wiersze mianem „chrześcijańskich” Stanisławowi Falkowskiemu jawił się raczej jako „prorok”, który „swoje objawienie czerpie” nade wszystko z ,potocznego doświadczenia osobistego" ${ }^{17}$. W znacznie częściej przywoływanej, rozpowszechnionej przez Mariana Stalę wykładni jest Białoszewski ,poetą metafizycznym", przy czym - jak podkreślał krakowski krytyk - metafizyczność jego dzieła łączy się przede wszystkim ,z zarysowywanym w jego granicach projektem egzystencjalnym" "18. Pamiętać trzeba, że już w 1956 roku w recenzji jego debiutanckiego tomu ,poetą metafizycznym” nazywał autora Obrotów rzeczy Czesław Miłosz ${ }^{19}$. Równie inspirująca okazała się kategoria epifanijności, przez Ryszarda Nycza uznana za „kluczowy dla Białoszewskiego sposób

15 Ibidem, s. 109. Najbardziej precyzyjnie duchową postawę Białoszewskiego próbował Sobolewski określić na początku książki, pisząc: „Używam kategorii sakralnych w stosunku do twórczości i życia poety, który nazywał siebie »niewierzącym«. Pisarstwo Mirona nabiera specjalnego znaczenia, gdy na nie spojrzeć jako na akt »dzikiej świętości«. Antropolog epoki ponowoczesnej Roger Bastide, autor książek Mistycyzm bez Boga, Socjologia snu, tak właśnie nazywał poszukiwania spontanicznego sacrum, pierwotnego transu doznawanego poza instytucjami Kościoła i społeczeństwa, które świętość »udomowiły«. Białoszewski mógłby być świetnym przykładem dla jego poszukiwań” (ibidem, s. 15).

16 Zob. T. Sobolewski, Szaman [w:] Miron. Wspomnienia..., s. 225, 228.

17 S. Falkowski, Pokorny prorok (dwa chrześcijańskie wiersze Mirona Białoszewskiego), „Ruch Literacki” 1985, nr 5-6, s. 462.

18 M. Stala, Czy Białoszewski jest poeta metafizycznym? [w:] Pisanie Białoszewskiego..., s. 113.

19 „Jest to poezja metafizyczna, w pierwotnym sensie określenia ta meta physika czyli to, co jest koło fizyki” (C. Miłosz, Dar nieprzyzwyczajenia. Nowy poeta polski, „Kultura” 1956, nr 10, s. 40). Diagnozę Stali poprzedzają także poświęcone Rozkurzowi i Wierszom dobranym sądy Krzysztofa Dybciaka, rozpoznającego w 1981 roku w „poezji metafizycznej” Białoszewskiego ,rzadko spotykaną w polskiej tradycji kulturalnej, a więc nadzwyczaj cenną estetykę ludycznej metafizyczności” (K. Dybciak, Trudne spotkanie. Literatura polska XX wieku wobec religii, Kraków 2005, s. 153). Zastanawiać mogła również nieco późniejsza diagnoza Dybciaka, uznającego Pamiętnik z powstania warszawskiego za ,jedną z bardziej ewangelicznych książek w polskiej literaturze współczesnej” (idem, op.cit., s. 144). 
przedstawiania, a zarazem podstawową zasadę organizacji semantycznej późniejszej jego twórczości”"20. Jak miało się okazać, w kolejnych poświęconych poecie tekstach metafizyczność i epifanijność nader często chadzały z sobą w parze; na przykład akcentujący rolę kontemplacji w jego twórczości Jarosław Fazan wieńczył swoje rozważania następującą formułą: „,poezja kontemplacyjna Białoszewskiego-pustelnika prowadzi do epifanicznego podziwu dla wszelkiego istnienia, do metafizycznego doznania zachwytu najbardziej trywialną scenerią egzystencji”21. Koncentrujący się na „drodze ciemności” Jana od Krzyża Jarosław Płuciennik pisał o „poetyce apofatycznej” Białoszewskiego $^{22}$, z kolei chętnie powołująca się na filozofię Martina Heideggera Elżbieta Winiecka uznawała jego poezję za formę ,świeckiej mistyki”, zbliżającą poetę do postawy zen i stanowiącą ,alternatywną drogę obcowania z sacrum - poza doświadczeniem wiary i objawienia"23. Nie dziwi, że odniesienia dalekowschodnie pojawiają się również w ostatniej monografii Beaty Śniecikowskiej, postrzegającej część tekstów autora Wyrw z zamyśleń jako „utwory, w których pomieszkuje hai-i, duch haiku”; choć badaczka zręcznie zdystansuje się od uznania go za poetę zen (,Zen Białoszewskiego [...] byłby wyjątkowo »osobny«, przykrojony na prywatną miarę, dla niektórych przez to prawdziwszy, dla innych - mętny, uproszczony, niepewny"), zachęci do spojrzenia na niego z perspektywy taoistycznej ${ }^{24}$. Z kolei dokonujący krytycznego przeglądu religijnych i mistycyzujących interpretacji twórczości Adrian Gleń zwieńczy go konkluzją, według której ,projekt życia kontemplacyjnego zawarty w tekstach Białoszewskiego nie ma nic wspólnego z kontemplacją religijną per speculum", a jego postawa $-\mathrm{z}$,wiarą religijną", w rezultacie czego autor Oho okaże się „dość zdecydowanym egzystencjalistą"25. Sceptycyzm ten wydaje się podzielać Joanna Niżyńska, chociaż i ona określa jego wczes-

20 R. Nycz, ,Szare eminencje zachwytu”. Miejsce epifanii w poetyce Mirona Białoszewskiego [w:] Pisanie Białoszewskiego..., s. 184 (przedruk w: idem, Literatura jako trop rzeczywistości. Poetyka epifanii w nowoczesnej literaturze polskiej, Kraków 2012).

21 J. Fazan, Ale ja nie Bóg. Kontemplacja i teatr $w$ dziele Mirona Białoszewskiego, Kraków 1998, s. 189.

22 J. Płuciennik, ,Będzie i będzie” Białoszewskiego? [w:] O wierszach Mirona Białoszewskiego. Szkice i interpretacje, red. J. Brzozowski, Łódź 1993, s. 75.

23 E. Winiecka, Białoszewski sylleptyczny, Poznań 2006, s. 184, 188.

24 B. Śniecikowska, Haiku po polsku. Genologia w perspektywie transkulturowej, Toruń 2016, s. 344, 388. Zdaniem badaczki do „poety z Lizbońskiej znakomicie stosują się słowa" Lin Tung-Chi z tekstu Umystowość chińska i jej taoistyczne podłoże, a fakt, że kontekst ów „nie stał się interpretacyjnym wątkiem twórczości poety”, uznaje ona za „zastanawiający" (ibidem, s. 345).

25 A. Gleń, ,W tej latarni...”. Późna twórczość Mirona Białoszewskiego w perspektywie hermeneutycznej, Opole 2004, s. 143, 190, 183. 
ną poezję mianem ,ppoetyckiej liturgii”26 - powtarzając w ten sposób starsze o ponad pół wieku ujęcie Jerzego Kwiatkowskiego z eseju Abulia i liturgia, w którym specyficzna ,„»sakralność« poezji Białoszewskiego” uznana została za „przejaw religijności zastępczej, religijności człowieka niereligijnego"27.

Wyrywkowy ów przegląd kontynuować można by jeszcze długo - do pojawiających się u Białoszewskiego motywów religijnych nawiązywali wszak badacze wielokrotnie i na różne sposoby: nadawali poświęconym mu monografiom zapadające w pamięć tytuły (jak Gramatyka $i$ mistyka Jacka Kopcińskiego, Ale Ja nie Bóg Jarosława Fazana czy Metafizyczne gospodarstwo Mirona Ewy Nofikow), nie unikali poczucia humoru (jak w quasi-podręczniku I ty możesz zostać mistykiem Tomasza Woźniaka ${ }^{28}$ ), w końcu zaś nie stronili od prowokacji (by przypomnieć tu tylko Artura Sandauera, rozpoznającego w decyzjach pisarskich autora Mylnych wzruszeń ,,postawę satanisty” ${ }^{29}$ ). Różnorodność ta wynika przede wszystkim z faktu, że w swojej twórczości - poetyckiej, teatralnej i prozatorskiej - szeroko rozumiany język religijny wykorzystuje Białoszewski nie tylko często ${ }^{30}$, ale także niemal zawsze nietypowo, ironicznie dystansując się od tradycji liryki religijnej i metafizycznej oraz podejmując z nimi przewrotną, ironiczną grę, niewolną od humoru i strategii profanacyjno-blasfemicznych. Idiomatyczne i innowacyjne zabiegi tego typu inspirować muszą krytyków i badaczy do interpretacyjnej inwencji - do czego zachęcają również świadectwa osób bliskich poecie, jak i publikacja tekstów rozproszonych i archiwalnych, na czele z Tajnym dziennikiem. Ze względu na znaczną liczbę i zwracający uwagę charakter występujących w tych tekstach religijnych odniesień (analizując niepublikowane dotąd poezje, uznać można wręcz, że inspiracje religijne należały do najtrwalszych w całej jego twórczo-

26 J. Niżyńska, Królestwo małoznaczacości. Miron Białoszewski a trauma, codzienność i queer, przeł. A. Pokojska, Kraków 2018, s. 48.

27 J. Kwiatkowski, Abulia i liturgia [w:] idem, Klucze do wyobraźni, Warszawa 1964, s. 164.

28 Zob. T. Woźniak, I ty możesz zostać mistykiem. Zestaw ćwiczeń z dodaniem dziewięciu wierszy Mirona Białoszewskiego, „Teksty Drugie” 1996, nr 2-3.

29 A. Sandauer, Poezja rupieci [w:] idem, Samobójstwo Mitrydatesa. Eseje, Warszawa 1968, s. 127.

30 Rozpoznanie to potwierdza sporządzony przez Jana Falkowskiego indeks postaci pojawiających się w jedenastu pierwszych tomach Utworów zebranych Białoszewskiego. Spośród jego pięciu części - Malarze, Kompozytorzy, Pisarze polscy, Pisarze obcy, Bóg, Biblia $i$ święci - to ostatnia jest najobszerniejsza; badacz odnalazł m.in. 185 odniesień do osób Trójcy Świętej, 77 do Matki Boskiej oraz 190 do świętych i postaci biblijnych (dla porównania: Bach pojawia się w 53 fragmentach, a Mickiewicz - jakże by inaczej - w 44). Zob. J. Falkowski, ,, Pan Mozart, pan Bach, pani Reginka, ja”. Spotkania z ludźmi i kultura w twórczości Mirona Białoszewskiego, Warszawa 2015. 
ści $\left.{ }^{31}\right)$ powinniśmy się spodziewać kolejnych literaturoznawczych formuł $i$ interpretacyjnych przybliżeń, mających na celu uchwycenie, nazwanie i opisanie właściwej postawy duchowej Białoszewskiego. Każda z tych prób będzie znacząca, a kolejne hermeneutyczne wglądy w twórczość poety mogą się jej tylko przysłużyć; tymczasem jednak (niech będzie, że zgodnie z ignacjańską zasadą agere contra) spojrzeć chciałbym na zarysowane do tej pory kwestie z pewnego dystansu.

\section{Duchowość - wolność - frywolność. Białoszewski i neoawangarda}

Co stanowi największą słabość „mironologii głębinowej”? Paradoksalnie - jej siła: składające się na nią rozpoznania to mimo wszystko interpretacje w ontologicznym sensie mocne, nierzadko pozostające w sprzeczności z praktyką pisarską Białoszewskiego, z nieodłącznymi odeń ironią i humorem, a w końcu z właściwym mu dystansem do kreowanych przezeń instancji podmiotowych ${ }^{32}$. W odczytaniach skupiających się na zadaniu uchwycenia filozoficznej czy duchowej postawy Białoszewskiego człowieka minimalizowana bywa też rola językowych zabiegów Białoszewskiego poety: pierwszego i najważniejszego przedstawiciela poetyckiego lingwizmu, obficie korzystającego ze zdobyczy awangard i stawiającego na eksperyment jako na podstawowy modus literatury. Marginalna rola odwołań Sobolewskich i Stali do koncentrujących się na wymienionych jakościach strukturalistycznych analiz Sławińskiego, Balcerzana czy Barańczaka nie jest przypadkiem; Niżyńska napisze wręcz o „ogromnej przepaści” rozciągającej się pomiędzy „metafizycznymi” a „lingwistycznymi” interpretacjami pisarstwa Białoszewskiego ${ }^{33}$. Pragnęłaby wreszcie „mironologia głębinowa" uchwycić to, co u autora Rozkurzu chyba jednak nieobecne - jakiś rodzaj struktury głębokiej wszystkich jego utworów czy też, inaczej rzecz ujmując, nadrzędną wobec nich niezmienną postawę filozoficzną. $\mathrm{Na}$ niebezpieczeństwo tego typu idealizujących wykładni wskazywała Grażyna Borkowska, upominając się o Białoszewskiego nieheroicznego i wyrażając przekonanie, że „Miron-filozoficzny nie zwycięża Mirona-pojękującego, że doznawane przez poetę olśnienia nie są nigdy - na szczęście! - czyste, że po-

31 Również w Tajnym dzienniku nie stroni poeta od rozważań dotyczących szeroko rozumianej sfery religijnej. Dla przykładu w zapisie jednej tylko rozmowy z Le. mowa jest o Faustynie Kowalskiej i jej ,nieprzyzwoitym” Chrystusie (,taki blondas z bródką, niebieskimi oczyma"), o hymnie Salve Regina, Ogrójcu, obrazie Matki Boskiej Częstochowskiej, a wreszcie o kościołach i klasztorach Warszawy (zob. TD, s. 303-309).

32 Zob. np. T. Kunz, ,Ja: pole do przepisu”. Miron Białoszewski, czyli literatura jako forma istnienia, „Teksty Drugie” 2006, nr 5.

33 J. Niżyńska, op.cit., s. 68. 
zostaje na ich dnie jakiś osad, zwątpienie, niepokój, wycofanie, rozmnożenie, już nie bytów, a wątpliwości" "34. Krytykę tę rozwinęła Joanna Orska, uznając, że propozycje interpretacyjne wychodzące $\mathrm{z}$, rozumienia tekstu poetyckiego jako tradycyjnie rozumianej epifanii, przedstawienia tego, co niewyrażalne wydają się pozostawać na z góry przegranej pozycji”, ponieważ „odnoszą się do poety, dla którego domeną poetyckich działań była wielorako rozumiana pograniczność" 35 . Upominając się o podejście odmienne, ,usiłujące rozmywać granice [...], reorganizować i unieważniać fundujące je hierarchie", zwracała badaczka uwagę na „happeningowość twórczości Białoszewskiego”, traktującego „sferę pomiędzy literaturą a codziennym, także językowym doświadczeniem” jako „naturalną przestrzeń eksperymentu” ${ }^{36}$. Ujęcie takie wpisuje autora Obrotów rzeczy w tradycję literackiej neoawangardy, w innym miejscu definiowaną przez Orską w kategoriach ,długofalowego, interdyscyplinarnego i wielowątkowego, polimorficznego powrotu do przedwojennych koncepcji awangardowych" ${ }^{37}$. Choć w odniesieniu do polskich jej przedstawicieli woli ona, co prawda, mówić o awangardzie „późnej” ${ }^{38}$, opóźnienie to nie wydaje się akurat dotyczyć beztrosko przechadzającego się na ich czele Białoszewskiego - od pewnego zresztą czasu dość często w kontekście neoawangardy sytuowanego. Najwcześniej łączono go z pop-artem: przywołując głośną $W y$ stawę sztuki popularnej Tadeusza Kantora, Stanisław Burkot uznawał w 1992 roku, że „w literaturze - na naszym terenie - właśnie Białoszewski wyciągnął najdalsze konsekwencje z możliwości odkrytych przez twórców pop-artu"39. Dla teatrologów oczywistym kontekstem interpretacyjnym sztuk twórcy Teatru Osobnego od zawsze były - obok Teatru Absurdu - happening i performance; Anna Krajewska zestawiała go ponadto ze sztuką Johna Cage'a ${ }^{40}$. Znacznie więcej neoawangardowych kontekstów - wyjąwszy wymienione, m.in. informel, action painting, ready made, kolaż i asamblaż - przynosi książka

34 G. Borkowska, „Pędy, rytmy”: jeszcze o Białoszewskim, „Teksty Drugie” 1995 , nr 5, s. 151 .

35 J. Orska, Życie jako happening. O artystyczności ,tajnego dziennika” Białoszewskiego [w:] Białoszewski przed „Dziennikiem”, s. 109.

36 Ibidem, s. 109-110, 101-102.

37 J. Orska, Nauka chodzenia. O tekstach programowych późnej awangardy [w:] Nauka chodzenia. Teksty programowe późnej awangardy, t. I, red. W. Browarny, P. Mackiewicz, J. Orska, Kraków 2018, s. 10.

38 Ibidem, s. 18.

39 S. Burkot, Miron Białoszewski, Warszawa 1992, s. 94. O pisarzu jako o ,poecie neoawangardowym” i ,poecie pop-artu”, ,od początku do końca” rozwijającym ,założenia pop-artu" pisał też T. Drewnowski (idem, Próba scalenia. Obiegi-wzorce-style, Warszawa 1997, s. 196, 198).

40 A. Krajewska, Białoszewskiego „,dramat osobny”, czyli „wypadek z genologii” [w:] Pisanie Białoszewskiego..., s. 227. 
Agnieszki Karpowicz, stanowiąca analizę późnej prozy Białoszewskiego ${ }^{41}$. Rzecz jasna przywołanie tych czy innych zjawisk, technik czy gałęzi sztuki nie musi oznaczać pełnego utożsamienia z nimi działań Białoszewskiego; na przykład zdaniem Winieckiej nie należy łączyć go „bezpośrednio ze sztuką neoawangardy”, gdyż ta stanowi dlań rodzaj „tła” czy „kontekstu, w którym osobność i oryginalność poety jeszcze bardziej się uwidacznia"42. Innego zdania będzie Alina Świeściak, nazywająca autora Obrotów rzeczy ,pierwszym polskim wcieleniem [...] świadomości neoawangardowej” i, dopowiadająca, że nie tyle ,przeszczepiał [on - dop. P.B.] na nasz grunt dorobek zachodniej neoawangardy”, ile - w serii ,działań paraartystycznych, efemerycznych [i dop. P.B.] rebelianckich" - sztukę neoawangardową tworzy ${ }^{43}$.

Nie tylko z uwagi na problematykę niniejszego tekstu najważniejsza wydaje się wszakże propozycja Ryszarda Nycza, istotna również dla Orskiej, odnajdującej w ,anty-metafizycznych [...] epifaniach awangardowych” Białoszewskiego - w których „świętość” okazuje się „funkcją samego spotkania przyjaciół jako swego rodzaju spektaklu"44 - cenną przeciwwagę dla propozycji Sobolewskiej i Stali. W istocie w strategii epifanii, niestanowiącej „osobnej formy czy gatunku wypowiedzi”, lecz „regulatywny ideał tego pisarstwa, centralną technikę przedstawiania oraz odśrodkową zasadę organizacji jego semantyki", udało się Nyczowi wyznaczyć punkt zbiegu trzech linii rozwojowych praktyki twórczej Białoszewskiego: „futurystycznego marzenia o prywatyzacji kodu i odzyskaniu przez podmiot języka; pokrewnej z duchem neoawangardy misyjnej działalności twórczej w środku zwykłego, codziennego życia oraz objawienia rzeczywistości”45. W zaprezentowanym w 1991 roku, podczas ważnej dla recepcji poety konferencji Instytutu Badań Literackich, tekście Nycza, obok pojęcia epifanii uwagę zwracać musiała jego silna teza, uznająca „ruch neoawangardowy za niezbędny kontekst wyjaśniający, który uczytelnia znaczenie artystycznych poszukiwań Białoszewskiego, ukazując je w szerszej perspektywie historycznoliterackiej i historycznoartystycznej" ${ }^{4}$. Choć rozpoznanie to stało się punktem odniesienia kolejnych literaturoznawczych przybliżeń, uznać można, że sam związek neoawangardy i epifanijno-

${ }^{41}$ Zob. A. Karpowicz, Kolaż. Awangardowy gest kreacji. Themerson, Buczkowski, Białoszewski, Warszawa 2007.

42 E. Winiecka, Białoszewski sylleptyczny, s. 185. W swojej następnej książce odczytywać będzie już badaczka „poezję i prozę Białoszewskiego [...] jako performansy” (eadem, Z wnętrza dystansu. Leśmian - Karpowicz - Białoszewski - Miłobędzka, Poznań 2012, s. 314).

43 A. Świeściak, Miron Białoszewski: alienacja i utopia. O neoawangardowych kontekstach poezji Białoszewskiego, „Poznańskie Studia Polonistyczne. Seria Literacka” 2014, nr 24, s. 277.

44 J. Orska, Życie jako happening..., s. 114.

45 R. Nycz, op.cit., s. 189, 190.

46 Ibidem, s. 182. 
ści nie został w nich dotąd przekonująco rozwinięty - a szkoda! Powracając bowiem do metafory przepaści rozciągającej się pomiędzy lingwistycznymi (awangardowymi) a metafizycznymi (religijnymi) wykładniami twórczości Białoszewskiego, zauważyć trzeba, że łączący oba brzegi most wzniesiony został przez Nycza ponad dwie dekady przed publikacją książki Niżyńskiej i bynajmniej nie runął, choć być może spowszechniał nieco, a autor dwutomowego przeglądu recepcji twórczości autora Byto i byto ${ }^{47} \mathrm{z}$ sobie tylko znanych powodów nie zechciał o nim pamiętać...

Zanim przez most przejdziemy, zauważmy, że, stapiając z sobą neoawangardowość i epifanię, zaproponował Nycz rozwiązanie istotnego dylematu, trapiącego znaczną część interpretatorów pism Białoszewskiego. Być może najuczciwiej problem ten wyartykułowany został przez Adama Zagajewskiego w omówieniu Szumów, zlepów, ciagów opublikowanym w 1977 roku w „Znaku”. Z jednej strony autora Drugiego oddechu wyraźnie intryguje ,życie duchowe” Białoszewskiego: stale „korzystającego z symboliki (ech symboliki) chrześcijańskiej”, „dostrajającego się do świąt i chrześcijańskiej tradycji”, wsłuchującego się w płyty „największych twórców muzyki liturgicznej”, nade wszystko zaś - z przykuwającą uwagę „frywolnością, szczególną poufałością" sięgającego do Biblii ${ }^{48}$. Z drugiej strony Zagajewski nie potrafi odnaleźć w historii życia duchowego postawy, jaka odpowiadałaby tej prezentowanej w czytanym przezeń „pamiętniku życia duchowego"49. Próbując wiązać ją z kontemplacją i cokolwiek heretycką mistyką (,tego rodzaju fragmenty zdają się wyznaniami mistyka, ale nie ortodoksyjnego, nie panteisty nawet, tylko reisty”), jak również (także bez przekonania) z postawą „specjalnego, artystowskiego personalizmu", odczuwa opór, którego źródłem okazuje się - jak w końcu orzeka - uległość poety wobec „mitu awangardy" ${ }^{50}$. Oto wydawał się Białoszewski pretendować do miana „pisarza chrześcijańskiego”, a jednak „zaważyła linia awangardowa, [...] pokręcona i przekręcona”, nade wszystko zaś „wywietrzała” i pozbawiona nawet

[...] najmniejszego powiewu tej świeżości, która niegdyś towarzyszyła początkom ruchów awangardowych. Białoszewski poszukuje więc pożywniejszych pokarmów, i okrężnie, przez furtkę od ogrodu, zakrada się do spichlerzy chrześcijańskich symboli, bo wyczuwa tam wciąż jeszcze wielkie bogactwo. Ale nawyki awangardowego estetyzmu nie dają się tak łatwo wytłumić, dlatego też kończy się na stylizacji, na cytatach z innej tradycji, na balu maskowym ${ }^{51}$.

47 Zob. P. Sobolczyk, Dyskursywizowanie Białoszewskiego, t. I-II, Gdańsk 2013-2014.

48 A. Zagajewski, W Warszawie jak na wsi [w:] idem, Drugi oddech, Kraków 1978, s. 104, 101, 103.

49 Ibidem, s. 98.

50 Ibidem, s. 105, 107, 106.

51 Ibidem, s. 106-107. 
Zamiast chrześcijańskiej epopei poznajemy w rezultacie „męki, jałowości i rozkosze awangardowego i ateistycznego ducha, którego męczy wielkie pragnienie", niedające się wszakże zaspokoić, gdy pozostaje się wiernym postawie ,awangardowego estetyzmu” - oto na „wytwory żarliwości religijnej patrzy Białoszewski z estetycznego punktu widzenia” i choć „objada się smakołykami z tamtej kuchni", strawa ta wydaje się Zagajewskiemu nieprawdziwa: „wszystko trochę na niby"s2.

Problemem diagnozy autora Sklepów mięsnych nie jest bynajmniej niechęć do Białoszewskiego ${ }^{53}$, lecz redukcjonistyczne rozumienie awangardy, w jego omówieniu stereotypowo sprowadzonej do postawy „estetyzmu” i utożsamionej wyłącznie ze zjawiskiem historycznym, z którego dziś pozostał co najwyżej szkodliwy i ograniczający „mit”. Oczywiste jest, że bardziej aprobatywne spojrzenie na projekt awangardowy, zakładające możliwość jego kontynuacji, pozwoliłoby lepiej opisać specyfikę intrygującej „Białoszewskiej” duchowości, a także otworzyłoby możliwość odmiennej konfiguracji (bardziej przecież niż w ujęciu Zagajewskiego złożonych) relacji między metafizyką a awangardą, (a)teizmem a estetyzmem, duchowością a eksperymentem, w końcu zaś - zgłębianiem religijnej problematyki a wykorzystywaniem religijnego języka. Propozycja Nycza wytycza drogę; chciałbym tu jedynie zaproponować uzupełnienie jej o trzy aspekty, których uwzględnienie pozwoliłoby - jak wierzę - uchwycić wspomnianą relację pomiędzy literaturą, religią i (neo) awangardą tak, by nie stracić $\mathrm{z}$ oczu prawdziwego skarbu wczesnego pisarstwa Białoszewskiego: unikalnego amalgamatu heretyckiego z ducha dramatyzmu i ludyczno-profanacyjnej frywolności, z jaką w latach pięćdziesiątych i pierwszej połowie sześćdziesiątych ,„podkradał się on do chrześcijańskich spichlerzy". Po pierwsze zatem uznać można, że nie oddał Nycz sprawiedliwości pochodzącym z tego czasu pierwszym tomom poety. Uznając je za przykłady ewokujących ,religijno-eucharystyczne konotacje” epifanii „tradycyjnych", omówił je cokolwiek zdawkowo, by znacznie obszerniejsze rozważania poświęcić odpowiadającym „dojrzałej i późnej fazie” pisarstwa Białoszewskiego, z założenia niejednoznacznym epifaniom ,nowoczesnym”, posiadającym Joyce’owski rodowód i niepotrzebującym już „,czerpać swej mocy z pożyczanej aury sakralności, bowiem objawiać mają prawdę o realności innego rodzaju: o doświadczeniu radykalnej czasowości istnienia,

52 Ibidem, s. 106, 103.

53 „Osobna” duchowość Białoszewskiego jest dla niego raczej ,intrygująca”, rozumie on jej znaczenie dla ,artystów wydziedziczonych”, docenia zaproponowaną przez poetę „regułę życia duchowego” (,to, co czyste, musi się zetknąć z nieczystym”), wreszcie zaś przyznaje, że „kontrast między młodością języka” (awangardowego), ,a sędziwością problematyki” (duchowej) „daje ciekawy efekt, przynosi coś świeżego i plastycznego” (ibidem, s. $105,102,106)$. 
przypadku i przemijalności” ${ }^{\prime 4}$. Po drugie, w swoim tekście przynajmniej bezpośrednio nie uwzględniał Nycz zachodzących w kulturze procesów sekularyzacyjnych, których dramatyzm szczególnie silnie odczuwano w czasie wojny, a które po 1945 roku odgórnie przyśpieszać próbowały władze programowo ateistycznej Polskiej Rzeczpospolitej Ludowej. Kontekst przemian Taylorowskiej „epoki świeckiej” - dochodzący do głosu w omówieniu Zagajewskiego, wspominającego o typowym dla pokolenia autora Obrotów rzeczy duchowym „wydziedziczeniu” i właściwym dla niego „trochę umownym, trochę spłowiałym sacrum" 55 - wydaje się dla wczesnych, ,sakralizujących" wystąpień poety co najmniej istotny. Po trzecie wreszcie, uwagę zwraca, że omawiając znaczenie wystąpień neoawangardowych i odnosząc się do pojęcia „świata sztuki” (artworld), nie akcentuje Nycz ich aspektu krytycznego, ale podkreśla rolę indywidualnej ekspresji; czytamy oto, że praktyki neoawangardowe (wśród których wylicza Nycz m.in. wykłady Cage'a czy eventy Fluxusu) stanowią:

[...] przedłużenie aktywności życiowej artysty, który nie angażując się w działania w ramach ponadjednostkowego systemu reguł konstytuujących autonomiczny „świat sztuki”, zmierza raczej do samorealizacji i zamanifestowania własnej indywidualności ${ }^{56}$.

To prawda, że tak „streszczoną [...] charakterystykę można odnieść [...] w całości do twórczości Białoszewskiego" ${ }^{57}$, czy jednak jego działania nie stanowiły jednocześnie krytyki obowiązującego w latach pięćdziesiątych w Polsce świata sztuki, a tym samym nie przekraczały paradygmatu artystycznego ujednostkowienia?

Rzecz jasna, wspominając o wyliczonych „brakach”, nie czynię z nich Nyczowi zarzutu. Jego tekst jest objętościowo niewielki, a przedstawiona w nim argumentacja konsekwentna i spójna: ponieważ interesują go przede wszystkim późniejsze teksy Białoszewskiego, skupia się na najbardziej dla nich charakterystycznym „,ucodzienniającym” typie epifanii, w którego opisie niekoniecznie trzeba akcentować procesy zeświecczenia czy krytyczny stosunek autora Obrotów rzeczy do panującej instytucji sztuki. Jeżeli jednak pochylając się nad pierwszymi trzema tomami Białoszewskiego, nie zadowolimy się uznaniem występujących tam epifanii za „tradycyjne” i zobaczymy w nich działania neoawangardowe, to odwołania do sekularyzacji oraz do ro-

${ }^{54}$ R. Nycz, op.cit., s. 184-185, 189. Uściśla Nycz, że pierwszy raz nowoczesny typ epifanii pojawił się u Białoszewskiego w cyklu Zajścia z tomu Mylne wzruszenia (ibidem, s. 185).
55 A. Zagajewski, op.cit., s. 103.
56 R. Nycz, op.cit., s. 181.
57 Ibidem. 
zumienia sztuki jako społecznego podsystemu staną się konieczne - podobnie jak przyjęcie tezy o pierwszeństwie Białoszewskiego w tej części powojennej literatury polskiej, którą określić można mianem postsekularnej.

\section{Przeszła sztuka (i wraca), przyszła religia (i poszła). Białoszewski i instytucje}

Intuicje powyższe uprawomocnić chciałbym, odwołując się do Teorii awangardy Petera Bürgera i utrwalonej tradycji postrzegania awangardy w ścisłym związku ze społecznym funkcjonowaniem sztuki oraz innych instytucji życia społecznego - a zatem także i religii. Jak wiadomo, Bürgerowskie rozumienie instytucji sztuki odsyła zarówno do ,aparatu służącego [jej - dop. P.B.] tworzeniu i dystrybucji”, jak i do ,panujących w danej epoce wyobrażeń na [jej dop. P.B.] temat, znacząco wpływających na recepcję dzieł" 58 , pojedyncze zaś działania artystyczne mogą ją tematyzować, podejmować z nią grę, a wreszcie przekształcać. Każda instytucja (każdy z podsystemów społecznych) rozwija się dzięki wewnętrznej „krytyce immanentnej”, którą w swojej książce omawia Bürger akurat na przykładzie religii. Za Karolem Marksem, wspominającym o „krytyce, którą stosowało chrześcijaństwo wobec pogaństwa czy też protestantyzm wobec katolicyzmu" 59 , przyjmuje Bürger, że „krytyka immanentna dla systemu w obrębie instytucji religii jest krytyką pewnych wyobrażeń religijnych w imię innych wyobrażeń. Inaczej - kontynuuje - jest z samokrytyką, która [...] zakłada dystans wobec zwalczających się wzajemnie wyobrażeń religijnych”, będący przejawem ,innej, w gruncie rzeczy jeszcze radykalniejszej krytyki, krytyki wobec samej instytucji religii" ${ }^{60}$. W tym miejscu wywodu Bürger porzuca religię, aby powrócić na teren estetyki i sformułować główną tezę swej książki: oto „wraz z historycznymi prądami awangardowymi społeczny podsystem sztuki wkracza w stadium samokrytyki”, oceniając ujemnie już nie tyle, jak w krytyce immanentnej, ,minione style, lecz instytucję sztuki, jaka rozwinęła się w społeczeństwie mieszczańskim" ${ }^{1}$. Jeśli zatem krytykę immanentną religii definiują kolejne etapy kształtowania się tej czy innej doktryny, to jej samokrytyka musiałaby być związana z procesami zeświecczenia, które sprowokowały pierwszych socjologów religii do sformułowania tak zwanej tezy sekularyzacyjnej. Jak czas pokazał, okazała się ona nieco przesadzona - podobnie jak Bürgerowska teza o zrównaniu sztuki

58 P. Bürger, Teoria awangardy, przeł. J. Kita-Huber, Kraków 2006, s. 27.

59 K. Marks, Przyczynek do krytyki ekonomii politycznej, przeł. E. Lipiński, Warszawa 1953, s. 253.

60 P. Bürger, op.cit., s. 27.

${ }^{61}$ Ibidem. 
z życiem, czego dokonać miały awangardy historyczne. Do wszelkich prób ponownego podjęcia tego gestu ma już jednak niemiecki teoretyk sztuki stosunek pejoratywny: „,neoawangarda, która na nowo inscenizuje charakterystyczne dla awangardy zerwanie z tradycją, staje się” jego zdaniem ,pozbawionym sensu przedstawieniem, dopuszczającym każdy możliwy sens"62.

Neoawangardę pomyśleć można jednak zupełnie inaczej - chociażby podążając za Halem Fosterem, który w eseju Kto się boi neoawangardy? rehabilituje tę ostatnią, podtrzymując jednocześnie Bürgerowską koncepcję dialektyki i starając się, jak powiada, argumentować zarazem z autorem Teorii awangardy, jak i przeciw niemu: zasadniczo niemiecki teoretyk miałby rację, lecz ,ślepy na eksperymentalną sztukę swoich czasów” wyciągać miałby „błędne” konkluzje na jej temat ${ }^{63}$. Na serii przykładów autor Powrotu Realnego pokazuje, że neoawangarda nie tyle bezrefleksyjnie powtarza dokonaną już samokrytykę instytucji sztuki, ile poszerza ją, zaś dzięki uzyskanej w ten sposób zwiększonej metaświadomości podjąć może jej „twórczą analizę” i proponować „nowe typy doświadczenia estetycznego" "64. Uwagę Fostera zwraca zwłaszcza „paradoksalna czasowość" kolejnych powrotów awangardowych impulsów, na skutek której wydają się one - jak powiada - ,powracać z przyszłości”65. Tak ujmowana neoawangarda byłaby „,bardziej nachträglich niż neo" i funkcjonowałaby zgodnie z Freudowską logiką naznaczenia wstecznego (Nachträglichkeit) - niewczesnego, specyficznie opóźnionego działania, którego doświadczyć można wyłącznie poniewczasie, za pośrednictwem zdarzenia późniejszego. Tak jak zdaniem Freuda wydarzenia teraźniejsze retrospektywnie naznaczać mogą wcześniejsze, stapiając się z nimi i nadając im nową sprawczość, tak działania neoawangardy współkształtują, a wręcz rekreują, właściwy sens ,pracy awangardy”, która jako taka - zdaniem autora Powrotu Realnego - ,nigdy nie zyskuje historycznej wagi czy pełni znaczenia w pierwszej instancji" ${ }^{\prime 6}$.

Powracając do Białoszewskiego, uznać chciałbym jego wczesną (choć w zarysowanym wyżej sensie zdecydowanie „niewczesną”) twórczość z lat pięćdziesiątych i sześćdziesiątych za postsekularną właśnie dlatego, że jest ona w najlepszym, Fosterowskim ujęciu neoawangardowa: twórczo analizuje i reinterpretuje zarówno instytucję sztuki, w obrębie której powstała, jak i - stanowiącą jedno z jej stałych pól odniesienia - instytucję religii, z którą przewrotnie dialoguje i z której języka korzysta. Najwyraźniej podwójność ta uwidacznia się w „rebelianckich w stosunku do oficjalnego nurtu sztuki”

62 Ibidem, s. 79.

${ }_{63}$ H. Foster, Kto się boi awangardy? [w:] idem, Powrót Realnego. Awangarda u schytku XX wieku, przeł. M. Borowski, M. Sugiera, Kraków 2012, s. 39.

${ }^{64}$ Ibidem.

65 Ibidem, s. 55.

${ }^{66}$ Ibidem, s. 54. 
i wymierzonych $\mathrm{w}$ „konwencjonalnie pojęte wartości i jakości estetyczne” ${ }^{67}$ scenicznych eksperymentach Białoszewskiego, przeprowadzanych wespół z Ludwikiem Heringiem i Ludmiłą Murawską w Teatrze Osobnym, wcześniej zaś w Teatrze na Tarczyńskiej Lecha Emfazego Stefańskiego. Oto zapraszając na odbywającą się w prywatnej przestrzeni mieszkalnej Szara mszę, stanowiącą zarazem rodzaj parateatralnego, świeckiego rytuału i bluźnierczą, nieomal czarną, parodię liturgii rzymskokatolickiej, nie tylko przedstawia Białoszewski nową sztukę, ale przede wszystkim prowokuje namysł nad miejscem tego, co religijne czy duchowe, w społeczeństwie, w jakim przyszło mu żyć. Opierając zaś swój dramat na lingwistycznych grach słów - takich jak:

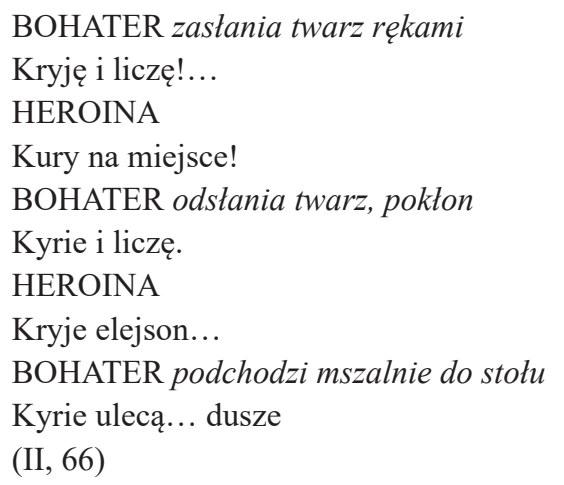

lub nieco dalej:

\section{BOHATER}

Prasuje żelazkiem, w którym i w żelazku duszą rozgrzaną do malinowości. HEROINA

Prasuje. Przefasonowuje.

BOHATER

Prefasuje.

HEROINA

Preface.

Bohater prasuje.

HEROINA

Prefacja??

(II, 67)

- nie tylko uwidacznia bliskość uświęconego języka religii i prozaicznej mowy „wszystkich naszych dziennych spraw”, ale i zadaje pytanie o możliwość religii jako zeświecczonej praktyki codzienności. Wchodząca w skład

${ }^{67}$ A. Świeściak, op.cit., s. 277. 
drugiego programu Teatru Osobnego Szara msza nie jest bynajmniej przypadkiem odosobnionym: język religijny obficie wykorzystywała już pochodząca z 1955 roku Wiwisekcja, w której rozważa się problem „Trójcowej schizofrenii” (II, 14), „modli się” do grzebienia „o przebłaganie” (II, 18), obserwuje się „wniebowzięcie” solniczki, nawiązuje do litanii, godzinek, nieszporów i kontemplacji, w końcu zaś przetwarza przypowieści o pannach mądrych i głupich oraz o „winnicowych robotnikach” (II, 23). Religijne odniesienia obecne są też w Wyprawach krzyżowych czy słynnych Osmędeuszach i choć bez wątpienia sprzyjają one parodii, prawdą jest również to, że - jak w odniesieniu do Wiwisekcji zauważa Kopciński - ,parodystyczne symbole” Białoszewskiego „dają jednak do myślenia”, sztukę tę czytać można jako „poetycki skrót ludzkich kontaktów z Najwyższym”, a wchodząca w jej skład „metaforyczna pieśń o zwykłym grzebieniu rzeczywiście wiele mówi nam o istocie biblijnego Stwórcy" ${ }^{98}$. Równie dużo dramat ów mówi jednak także o religii jako o więzi, o teatrze jako narzędziu wiwisekcji, mającej odsłonić i zbadać niewidoczny gołym okiem teologiczny krwiobieg sztuki, wreszcie zaś - o społeczeństwie, na którego żywej tkance tę wiwisekcję się przeprowadza, a którego członkowie stale wybuchają przy tym śmiechem. Wydaje się, że w akademickim opisie wielowymiarowość tę unieść może jedynie połączenie namysłu nad twórczością Białoszewskiego rozumianą jako seria praktyk neoawangardowych z refleksją o charakterze postsekularnym.

Podążając zatem za Fosterem, zobaczyć można relację postsekularyzmu i sekularyzmu w taki mniej więcej sposób, w jaki postrzega on związek neoawangardy i awangardy w kontekście społecznego podsystemu sztuki. Analiza postsekularna stanowi wszak „twórczą analizę” instytucji religii, analizę „zarazem specyficzną i dekonstrukcyjną”, niebędącą już jednak - jak pewne postaci wojującego sekularyzmu - ,nihilistycznym, abstrakcyjnym i anarchistycznym atakiem", lecz znacznie bardziej subtelną reinterpretacją, umożliwiającą aktywność ,przemieszczania” i „powolnego przepracowywania” tego, co sakralne, duchowe, religijne ${ }^{69}$. W taki też sposób - tyleż założony, ile, jak czytamy w słynnym Tłumaczeniu się z twórczości (I, 165), „po toczny”na nowo ,po tworzyłby” poeta sztukę odnoszącą się do religii, nasze doświadczenia religijne, a w pewnym sensie i religię samą, w efekcie czego, podobnie jak we właściwym dla neoawangardy paradoksalnym modelu ,powrotu z przyszłości"70, religia wydaje się tu „po wracać”: przyszła, prawdziwsza,

68 J. Kopciński, Gramatyka i mistyka. Wprowadzenie w teatralna osobność Mirona Białoszewskiego, Warszawa 1997, s. 58, 109.

69 H. Foster, op.cit., s. 46.

70 Wskazując na jego wagę dla takich myślicieli, jak Jacques Lacan, Gilles Deleuze czy Jacques Derrida, Foster podsumowuje swe rozważania nośnymi formułami tego ostatniego: „Na początku było opóźnienie” oraz „Idea pierwszego razu stała się zagadką” (J. Derrida, Freud i scena pisma [w:] idem, Pismo i różnica, przeł. K. Kłosiński, Warszawa 2004, s. 202-203; cyt. za: H. Foster, op.cit., s. 57). 
przetworzona. W naszkicowanej perspektywie twórczość Białoszewskiego konsekwentnie uznać należałoby nie tyle za poddaną postsekularnej analizie ex post, ile za postsekularną par excellence: to ona wszak „badała” i „postsekularyzowała" pojemność właściwych jej instytucji religii i literatury (sztuki), testując ich wyporność i poszukując słabych punktów ${ }^{71}$. Szczęśliwie nad analizą ram funkcjonowania dyskursu teologiczno-religijnego w programowo ateistycznym społeczeństwie Polski Ludowej, przeprowadzaną w cieniu Auschwitz i na zgliszczach powstania warszawskiego, nie zaciążyły resentyment i nostalgia. W poetyckim laboratorium Białoszewskiego przybrała ona postać eksperymentalnego testowania żywotności szeroko rozumianego języka religijnego, testowania odbywającego się za pomocą - celnie uchwyconej przez Stanisława Barańczaka - ,stałej tendencji do profanacji sacrum i sakralizacji profanum" "72. Pozwalała ona debiutującemu poecie zwracać się w modlitewnej apostrofie do podłogi (Podłogo, błogosław!), przeistaczać ciemną „grotę” pokoju w rozświetlony „magazyn kontemplacji” ( $O$ mojej pustelni $z$ nawoływaniem, I, 70) czy też - ,na drodze trawestacji wzorców litanijno-modlitewnych" "73 - wygrywać na stopniach schodów, półkach szafy i kolejnych piętrach kamienicy ekstatyczne tony eschatologicznego Autoportretu:

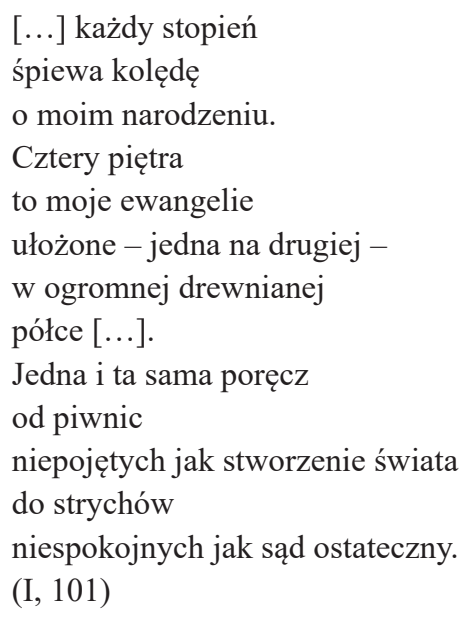

Jeżeli zabiegi te - których wyliczenie kontynuować można by długo, wyróżniając wśród nich m.in. profanujące przetworzenia rozmaitych pieśni religijnych, np. kolęd w wierszach Nawotuja po jakiemu (VII, 41) czy Podnióst-

71 Za dyskursywną próbkę analizy tego typu uznać może fragment Tajnego dziennika, w którym poeta zastanawia się, dlaczego - mimo licznych podobieństw - „socjalizm jest w jakiś sposób mniej udany od Kościoła chrześcijańskiego" (TD, 490).

72 S. Barańczak, Język poetycki Mirona Białoszewskiego, Wrocław 2016, s. 205.

73 Ibidem, s. 207. 
bym rękę (VII, 101) - dawać mogły efekty unikatowe i inspirujące, to w dużej mierze dzięki temu samemu zeświecczonemu i zdystansowanemu spojrzeniu na religię i metafizykę, które Zagajewski demaskował jako „nawyk awangardowego estetyzmu". Choć w Ttumaczeniu się z twórczości ,po toczne po tworzenie” przeciwstawione zostało oczekiwaniom krytyków-realistów („,chcą od mojego pisania nabrania życia otoczenia”, I, 165), to przecież Białoszewski - „łapiąc za słowa” - istotnie ich i życie „,nabiera”: robiąc psikusa i odpowiadając na potwarz ,po tworzeniem”, niebędącym wszak mimetycznym odwzorowaniem „otoczenia”, lecz awangardową z ducha próbą jego „po nownej" konstrukcji. Otwiera to możliwość parodii, pastiszu, groteski, profanacji, blasfemii czy też - jak ujmie to Adrian Gleń - „zabawnych eksperymentów z wywoływaniem uczucia nieskończoności" ${ }^{74}$. To właśnie „zabawność” wydaje się u Białoszewskiego kluczowa, stała zaś obecność w jego pisarstwie dystansującego poczucia humoru pozwala - za Johnem McClurem - uznać je za „postsekularną komedię duchową", cechującą się postawą religijnej „,trzeźwości" i niepozwalającą ,,ponownie poddać się zaczarowaniu"75. To dzięki nieodłącznej „m’ironii” tak umiejętnie łapie Białoszewski za słowa zwracające się do mieszkańca PRL-u z bardzo konkretnymi przekazami instytucje państwa ludowego i religii katolickiej oraz „po tworzy” z nich nowe, przekraczające ich granice, formy doświadczenia - czego emblematycznym przykładem jest zdolność dostrzeżenia betlejemskiej „stajenki” w wołomińskiej „budce z piwem”, „codniejącej” „dla trzech/ pasterzy w waciakach,/ stebnowanych króli”, śpieszących ku niej, by raz jeszcze odprawić swój birbancki „obrządek" (Filozofia Wołomina, I, 44-45). Potoczna, peryferyjna i półprywatna poezja Białoszewski nie tyle zwalcza przechwycone wyznania i deklaracje, ile skutecznie osłabia ich wymowę, sytuując je w sferze neoawangardowego niezdeterminowania, w której każde prawo i każde credo współistnieć muszą z innymi na zasadzie ,niekonfliktowego konfliktu" "76.

Wyłaniająca się z namysłu nad twórczością Białoszewskiego - oraz innych, wiele mu zawdzięczających poetów teolingwistów, wśród których jednym tchem wymienić należałoby Tymoteusza Karpowicza, Witolda Wirpszę, Krystynę Miłobędzką czy Stanisława Barańczaka ${ }^{77}$ - najkrótsza, społeczna definicja literatury postsekularnej brzmiałaby zatem następująco: jest to twórczość poddająca przemieszczającej, krytycznej analizie zarówno instytucję religii, jak i instytucję literatury. $Z$ uwagi zaś na niekwestionowany wpływ autora Obrotów rzeczy na dalsze losy literatury i eksperymentalnego teatru

74 A. Gleń, op.cit., s. 153.

75 J. McClure, Pótwiary. Literatura postsekularna w czasach Pynchona i Morrison, przeł. T. Umerle, Kraków 2016, s. 31, 183.

76 A. Świeściak, op.cit., s. 275.

77 Zob. P. Bogalecki, Szczęśliwe winy teolingwizmu. Polska poezja po roku 1968 w perspektywie postsekularnej, Kraków 2016. 
w Polsce postawić należałoby tu również tezę ogólniejszą, zgodnie z którą oddziaływanie awangardowych stylów odbioru stanowi czynnik sprzyjający podjęciu artystycznych poszukiwań o charakterze postsekularnym. Inaczej wreszcie rzecz ujmując: jeżeli istnieje uprzywilejowane podejście do znaku charakteryzujące postsekularne interwencje artystyczne, mogłoby nim być wyłącznie podejście neoawangardowe - oparte na modelu różnicującej repetycji i w nietrywialny, choć także nieantagonistyczny sposób modyfikujące instytucjonalne ramy funkcjonowania tego, co literackie (artystyczne), oraz tego, co religijne (duchowe).

\section{Rachunki wzruszenia. Białoszewski i sąd (nieostatecznie)}

Opublikowana niedawno archiwalna spuścizna Białoszewskiego przynosi inną wersję Ttumaczenia się z twórczości, za jaką uznać można opatrzony datą 25/28 I 60 wiersz spowiedź na głos (stuszny?):

bardzo grzeszyłem artystycznie

bardzo grzeszyłem estetycznie

dla wzruszeń

dla głosek

dla małych poruszeń

będę się szukał poruszać

żeby się zmuszać tak żeby

wzruszać potrzeby sobą

a nie siebie z potrzeby

(XIII, 172)

Oczywistą kanwę zacytowanego zapisu stanowi Confiteor - spowiedź powszechna, odmawiana „na głos” w trakcie eucharystycznych obrzędów wstępnych; zaczerpnięte stamtąd wyznanie „bardzo zgrzeszyłem” powtarza Białoszewski dwukrotnie, do następującego po nim trzykrotnego mea culpa odsyła zaś repetytywnością pierwszej części swego tekstu (dwa zdania, dwa przymiotniki, trzy wyrażenia przyimkowe ze słowem „dla”). Choć łącząc tę akurat część liturgii z tematyką metaliteracką, naprowadza nas poeta na tropy dobrze znane (Charles Baudelaire, Stanisław Przybyszewski), a jego „spowiedź” zachowuje rodzaj właściwej jego wielkim poprzednikom blasfemicznej przekory, nie poprzestaje on bynajmniej na prowokacji i kieruje nas dalej - ku światłu (tak bowiem określić można efekt typograficznego rozsunięcia pojawiającego się między wyznaniem ,grzeszyłem" a uzupełniającymi je przymiotnikami ,artystycznie” i „estetycznie”). Wprowadzająca czas przyszły druga część wiersza, choć nie odwołuje się już do spowiedzi bezpośred- 
nio, wydaje się odpowiadać koniecznej jej części - postanowieniu poprawy. $\mathrm{Na}$ to, co w nim najważniejsze, wskazuje Białoszewski lingwista w krótkim zapisie eksponującym pokrewieństwo podstawowych, powtarzających się w nim leksemów: „poruszeń” - „poruszać” oraz „wzruszeń” - „,Wzruszać”. Ich rdzeń odsłania przed nami zasadę organizacji poetyckich światów autora Obrotów rzeczy, jaką - także i w spowiedzi na głos - jest ,ruch” znaków i znaczeń. Profanujące język religijny artystyczne „grzechy” popełnia się tu „dla wzruszeń", które okażą się z kolei decydujące dla kończącego wiersz frapującego chiazmu: „wzruszać potrzeby sobą/ a nie siebie z potrzeby”. Co miałoby to oznaczać? Być może to, że celem twórczości Białoszewskiego nie byłaby chęć dostarczenia sobie i innym tego czy innego typu „przeżyć”, hołdujących mniej lub bardziej wyszukanej ,potrzebie” i usprawiedliwiających nawet najbardziej dziwaczne lingwistyczne ,poruszenia”. Byłoby raczej na odwrót: skoro to te ostatnie miałyby ,wzruszać potrzeby”, to czasownik „wzruszać” powinno się rozumieć w mniej oczywistych znaczeniach: specjalistycznym 'poruszając czymś, spowodować dostawanie się powietrza pomiędzy drobne kawałki tworzące jakąś całość' oraz archaicznym 'wprawić coś w ruch'. Mówiący w wierszu postanawiałby „wzruszać potrzeby sobą" - a zatem wypełniać sobą (swą idiomatycznością, wyobraźnią, życiem) monolit „grzeszności” i ,potrzeby", który tym samym wzruszałby z posad i rozszczelniał. Afirmacja ruchu wydaje się tu oczywista; znacznie ciekawsze okazuje się jednak to, że program przemian, $\mathrm{z}$ taką lekkością nakreślony przez poetę, trafia $\mathrm{w}$ samo serce chrześcijańskiej idei metanoi tudzież - jak czytamy w innym miejscu - „nawracania siebie” (swoja niełaska, I, 241). Nie negować siebie jako „grzesznego", bo ulegającego potrzebom - lecz podjąć trud (czytamy wszak o „zmuszaniu się") przemiany samych potrzeb. Z religijnej kruchty program ten przenosi poeta na codzienną praktykę artystyczną, nabierającą przez to znamion życia duchowego i upodabniającą pisanie do ascetycznej pracy nad sobą. Artystyczny trud „wzruszania potrzeb sobą” znosi zaś klincz opresyjnej triady potrzeba-grzech-pokuta, z której ostaje się jej najcenniejszy, choć najbardziej zeświecczony element - praca $^{78}$. Czy nie należałoby uznać, że specyficznie ascetyczny tryb życia Białoszewskiego, owego świeckiego świętego ożywającego we wspomnieniach przyjaciół, był wynikiem decyzji o codziennym happeningowym odgrywaniu przetworzonej w ten sposób struktury spowiedzi ${ }^{79}$ ? Wykonywana „na głos” przy akompaniamencie fałszywie asce-

78 Por. A. Bielik-Robson, Od Natury do Historii. Efekt Lutra u Hegla, „Konteksty” 2018, nr 3 .

79 Wbrew pozorom spowiedź pojawia się w poezji Białoszewskiego dość często: począwszy od otwierającego debiutancki tom Fioletowego gotyku, w którym ,pobożny przechodzień/ pod gwiazdą sklepienia/ całuje kamienne kolana:/ „zgrzeszyłem...«" (I, 10), poprzez prośbę ,rozgrzesz mnie!” i odpowiadający na nią „odpust poezji” z wiersza $O$ mojej pustelni z nawoływaniem (I, 69), wymowny tytuł drugiego tomu (Rachunek zachciankowy) 
tycznych ideałów PRL-u ,spowiedź” ta nie mogła nie uderzać w tony niewygodne zarówno dla Kościoła, jak i partii - a także dopiero co przebudzonych z socrealistycznego koszmaru literatury i sztuki.

W opublikowanym rok później (w 1961 roku) tomie Mylne wzruszenia (sic!) nie przez przypadek przedstawi się zatem Białoszewski następująco:

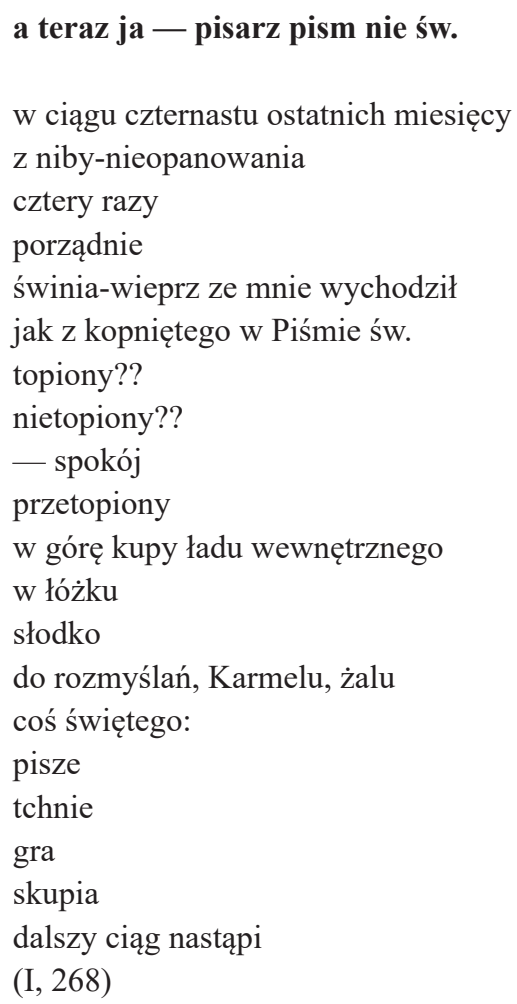

Przytoczony utwór pochodzi z obficie wykorzystującego chrześcijańską topikę cyklu Lė̇enia, już w 1972 roku interpretowanego pod tym kątem przez Henryka Pustkowskiego. Odczytując poezję Białoszewskiego jako ,infiltrację swoistego "mistycyzmu« wywodzącego się z góry Karmel", dostrzegał badacz jego przejawy już w Obrotach rzeczy (nawiązania do Eliasza i Elizeusza w wierszach $O$ mojej pustelni z nawoływaniem oraz Stołowa piosenka prawie

czy nieopublikowany liryk Więcej grzechów pamiętam (XIV, 9), do - by zatrzymać się w tym miejscu - Mojego brzęczenia z tomu Odczepić się, zawierającego wyznanie: ,ja w tej kulturze, w tym obrządku/grzeszyłem i niech mnie kto rozgrzeszy/ po takiemu" (VII, 57). Ze spowiedzia na głos (słuszny?) wydaje się dialogować, również nieopublikowany za życia poety, krótki zapis bez tytułu: „(do spowiedzi - ) mało?/ małe poruszenie/ byle czego/ z malutkiej cząstki/ wielkiego powodu" (XIII, 104). 
o wszechbycie), jednak wymowę proponowanych przez poetę ,poronnych, parodystycznych realizacji” sprowadzał do „obrony własnej prywatności”80. Inaczej niż Pustkowski, intuicyjnie oddzielający porządki tego, co intymne, i tego, co instytucjonalne (,Białoszewski ceni bardziej na swej górze odosobnienia świadomość poetycką niż jej instytucjonalne realizacje"81), tak prowokacyjne upublicznianie tego, co prywatne, odczytywać wolałbym jako krytykę fundującej je opozycji; wszak już w decyzji o wydzieleniu w ideologicznej przestrzeni Polskiej Rzeczpospolitej Ludowej prywatnej poetyckiej ,pustelni” dostrzec można krytyczne, polityczne znaczenie. Wyróżniająca się w cyklu Leżenia bezprecedensowa i bezpretensjonalna autoprezentacja (,a teraz ja — pisarz pism nie św."') nie chce być bynajmniej gestem defensywnym czy intymistycznym; przeciwnie - podniesiona do rangi tytułu wydaje się dumnie (,a teraz ja”) pogrywać ze społecznym rozumieniem pisarstwa i religii.

Dzięki użyciu skrótowca ,św.” już sam tytuł wiersza iskrzy możliwościami zróżnicowanych odczytań: jego sylleptyczny podmiot może przedstawiać się jako „,pisarz pism nie-świętych”, ,pisarz pism nie-święty”, a także - co wydaje się sugerować treść - ,pisarz pism nie świnia” bądź analogicznie: ,„pisarz pism nie-świńskich" (w odwodzie zaś pozostawałoby jeszcze prawnicze rozwinięcie skrótu św. jako świadka). Efekt blasfemicznego zbliżenia ,świętego" i ,świni” osiąga Białoszewski w wersach czwartym i piątym, bezpośrednio odsyłających do ewangelicznych intertekstów (Mk 5, 1-20; Łk 8, 26-39): choć w wielbionej przezeń Biblii Wujka mowa jest wyłącznie o ,wieprzach”, z uwagi na obecność grupy „św.” sięga poeta po złożenie „świnia-wieprz”, skutecznie zohydzające „Pismo św.” z kolejnego wersu ${ }^{82}$. Skażenie to znajduje swój ekwiwalent na płaszczyźnie treści - oto w stosunku do ewangelii znacząco odwrócony zostaje sens Jezusowego wypędzenia. ,Z kopniętego w Piśmie św." wygnani zostali - czytamy u Wujka - ,duchowie nieczyści”, którzy tuż po tym „wchodzą w wieprze” (Mk 5, 13). U Białoszewskiego Jezusa ze świecą szukać; mamy jedynie wyznanie: „świnia-wieprz ze mnie wychodził”, niemogące nie odnosić się do potocznego 'wyszła z niego świnia'. Motywacja lingwistyczna idzie tu w parze z umotywowaniem sytuacyjnym. Oto, podobnie jak w spowiedzi na głos (stuszny?), pierwsze wersy analizowanego tekstu wydają się stanowić próbę zapisu rachunku sumienia - autor Rachunku zachciankowego kładzie wszak na szali konkretne liczby i okoliczności ulegania „potrzebom”: „w ciągu czternastu ostatnich miesięcy/ z niby-nieopanowania/

${ }^{80}$ H. Pustkowski, Rodowód „Góry odosobnienia” [w:] idem, „, Gramatyka poezji”?, Warszawa 1974, s. 60, 70.

81 Ibidem, s. 70.

82 Fazan w rozwijającej intuicje Pustkowskiego rozbudowanej interpretacji Leżeń zwraca uwagę, że jeszcze wyraźniej zestawia poeta świętych i świnie w jednym z wcześniejszych wierszy cyklu, zawierającym frazę: „i ty poza świętych ze świń nic” (muźnięty, I, 240). Zob. J. Fazan, op.cit., s. 105. 
cztery razy/ porządnie" (I, 266). Wystarczająco czytelnie zasugerowana wydaje się też (homo)seksualna materia grzechu. W Ewangelii św. Łukasza czytamy, że „mąż, co miał czarta, nie obłóczył się w odzienie” (Łk 8,27), w obu zaś perykopach akcentowana jest jego „nieczystość”, konotowana również przez symbolikę świni. Jednak w koncepcie Białoszewskiego obecność tej ostatniej okazuje się warunkiem osiągnięcia „spokoju” i ,ładu wewnętrznego”. Jak słusznie zauważa Fazan, „topienie się duchów-świń w wodzie” zostaje tu językowo „skojarzone z... przetapianiem słoniny w spokój - »w górę kupy ładu wewnętrznego "" do ,słodyczy”, a w prywatnej mitologii Białoszewskiego oznaczająca charakterystyczną kołdrę, dobrze znaną jego licznym gościom i stanowiącą obiekt kilku anegdot (,,jak byłem na karmelni/ ciągnęli ten karmel ciągnęli/ przez sale przez maszynki/ a on szedł/ te takie pasy jak na mojej kołdrze/ stąd Góra Karmel"; cyckam karmel, I, 234). Uznać można, że wprowadzając do swej poezji znaczenia tak wyraźnie odsyłające do codziennej praktyki życiowej, odprawia Białoszewski rodzaj happeningowego rytuału, raz jeszcze podejmując awangardową próbę zniesienia granicy oddzielającej sztukę od życia.

$\mathrm{Na}$ tym jednak nie koniec. W wierszach z cyklu Leżenia tego typu „domowe" sensy stale nakładają się na znaczenia religijne, uprywatniając te ostatnie i umożliwiając lekturę całości w odniesieniu do diagnozowanego i dyskutowanego przez socjologów zjawiska prywatyzacji religii. Sytuowany w społecznym kontekście pustelniczy etos Białoszewskiego odczytywać można jako prowokacyjną w swym radykalizmie (vide: zaklejanie okien czarną taśmą, nocne czuwanie, posty itd.) odpowiedź na właściwą dla PRL-u sekularyzację odgórną. Rzecz jasna niezbywalny element humoru przeistacza „pseudo-karmelitańskie eksperymenty Białoszewskiego" ${ }^{84}$ wraz z proponowaną w Leżeniach postawą „kontempsiumplania” (*** [zgubić się], I, 271) w rodzaj blagi; czy jednak jej adresaci mogli być pewni, że blagą tą nie błaga Białoszewski o coś więcej? Jeśli uważnie przeczytali a teraz ja - pisarz pism nie św., pewności takiej mieć chyba nie mogli. Choć na pozór wiersz ów jedynie używa biblijnej perykopy, w istocie niesie z sobą - faktycznie uduchowioną, choć, rzecz jasna, nieco heretycką - jej egzegezę. To, że ,świnia-wieprz ze mnie wychodzi” jawi się w niej wszak (podobnie jak ewangeliczne „wyjście czorta") jako błogosławieństwo: karmi życie wewnętrzne, dając - co uwidacznia rozpoczynający drugą część tekstu myślnik - „do rozmyślań, Karmelu, żalu”; staje się zatem pożywką dla duszy, krzepi, czyni lepszym. Swojego świństwa nie mogę jednak próbować „topić”, co zdradzałoby duchową naiwność i zatrzymywałoby mnie w błędnym kręgu winy, odkupienia i kary; powinienem raczej cierpliwie ,przetapiać” je w ocalający wewnętrzny ład, wzruszenie rozpamiętywane $\mathrm{w}$ spokoju, w poezję. Jak wynika $\mathrm{z}$ wiersza (lecz już nie z pery-

83 Ibidem, s. 119.

${ }^{84}$ Ibidem, s. 47. 
kopy), to z owego „przetopienia”, odpowiadającego skupionej pracy metanoi, rodzi się „coś świętego”, co (niczym Duch św. w nas) „pisze/ tchnie/ gra/ skupia”, a wreszcie pozwala żywić nadzieję - i to (by wziąć wreszcie pod uwagę mistyczne znaczenie Karmel) nadzieję zaiste mesjańską. To dzięki pracy ze świństwem „dalszy ciąg” może „nastąpić"85. Chociaż w Mironowych „pismach nie św.” nie ma Chrystusa, pomieszkuje w nich nadzieja: świecka i nie-święta, lecz przecież zachowująca teologiczny sens grzechu jako szczęśliwej, ocalającej winy.

Skoro w heretyckiej ,,poetologii” (,poteologii”) Białoszewskiego za grzech nie płaci się śmiercią, nie może być w niej również miejsca na sąd; notuje poeta: „od kilku lat stwierdziłem, że sąd ostateczny nie jest mi już potrzebny” (TD, 466). Przenikająca frywolne i bezpretensjonalne działania autora Szarych eminencji zachwytu nieobecność sądu jawi się jako centralna idea jego Kalejdoskopu - sztuki opatrzonej podtytułem Komedia końca świata, którą McClure z pewnością zaliczyć mógłby do postsekularnych komedii duchowych. Sztukę tę (zdaniem Leszka Solińskiego powstałą już w 1951 roku; zob. XIII, 368) uznać można za wczesny tekst Białoszewskiego o największej sile społecznego oddziaływania - w roku jego poetyckiego debiutu została ona wyemitowana na antenie Polskiego Radia jako słuchowisko z udziałem tak znanych aktorów, jak Jan Kurnakowicz, Jan Kreczmar czy Aleksandra Śląska. Dramat rozpoczyna się obrazem „tłumów biegnących” na Sąd Ostateczny, jednak wezwanie uwspółcześnionej Sybilii („Uwaga! Uwaga! Proszę do końca zachować spokój, proszę się opanować i nie siać paniki. [...] Na wszystkich ulicach ruch jednokierunkowy") ignoruje Poeta, już w trzeciej swej wypowiedzi przedstawiający się jako ,niewierzący” (XIII, 305-306). Pozostając w pokoju i beztrosko zabawiając się kalejdoskopem, wchodzi w dialog ze zdążającymi na sąd Michelangelem, Dantem i Beethovenem. Choć artyści zachwycą się podsuniętą im zabawką, wybrać muszą odbywającą się „,w cudownie poszerzonej dolinie Jozafata” „uroczystość” końca świata, w trakcie której zaprezentowane zostaną ich wiekopomne dzieła (XIII, 307). Jako ostatni zagai Poetę nieśpiesznie zdążający w stronę ustawionej w dolinie Drabiny Jakubowej Bóg, który również zainteresuje się kalejdoskopem. W odróżnieniu jednak, jak z sympatią powie, od „tych trzech nicponiów, zawadiaków” (XII, 319) zafascynuje się nim tak bardzo, że poprosi, by Poeta dał mu go w prezencie. Dramat kończy niespodziewana zapowiedź uśmiechniętego Boga: „O, o, bardzo ci dziękuję, i jeszcze ci coś powiem: nie zrobię im żadnego Sądu, żadnego. Tylko wejdę na tę drabinkę i spojrzę w kalejdoskop. Może ułoży mi

85 W tym akurat wypadku trudno zgodzić się z odczytaniem Tadeusza Sobolewskiego, zdaniem którego ,nadzieja na przetopienie »w górę kupy ładu wewnętrznego« okazuje się płonna" (T. Sobolewski, Człowiek Miron..., s. 101) - a już tym bardziej z wypaczającym sens wiersza pominięciem wersów „słodko/ do rozmyślań, Karmelu, żalu/ coś świętego” w jego przytoczeniu na s. 103. 
się jakiś nowy, piękniejszy, lepszy świat" (XIII, 322). Dar Poety sprawia, że - niczym w kalejdoskopie - zmienia się zapowiedziany z dawien dawna Boży plan zbawczy, koniec świata nie następuje, a eschatologiczna Drabina Jakuba staje się zarzewiem tego, co nowe. Budzący grozę Sąd odwołany zostaje dzięki „ciekawostce”, stanowiącej źródło „niewinnej przyjemności”, a przez Boga określanej jako ,nawet wesołe widowisko, i niewinne, faktycznie niewinne" (XIII, 320). Wydaje się, że zabawa kalejdoskopem nie przez przypadek ujęta zostaje tu w sposób nasuwający na myśl estetykę Immanuela Kanta z jej apologią bezinteresownego piękna i definicją poezji jako „zajmującej gry wyobraźni”, która „niejako bawi się oglądaniem kształtu”, nie podlegając ograniczeniom celu i przedstawienia ${ }^{86}$. Poeta wybiera kalejdoskop, ponieważ jego układy i konstelacje sytuują się poza wszelką celowością i podobieństwem, a co za tym idzie - poza światem, którego koniec wydaje się go zresztą w sztuce w ogóle nie interesować, choć przecież to on, zapraszając Boga do zabawy, ratuje świat i utrzymuje go w istnieniu. Można zaryzykować twierdzenie, że w Kalejdoskopie Białoszewski artykułuje swe artystyczne - zarazem teologiczne i najgłębiej świeckie - credo: świat może zostać z(a)bawiony, jeżeli w swoich działaniach zdołamy zachować wobec jego Wielkich Problemów postawę błogosławionego niezaangażowania. To ostatnie jawi się jako postawa nieomal święta, zdolna przemienić świat, (w) którym się bawimy; lingwistycznie bezcelowe obroty słów to jednocześnie Obroty rzeczy, podobnie jak zadanie ,wskrzeszenia rzeczy” okazało się dla Wiktora Szkłowskiego Wskrzeszeniem Słowa ${ }^{87}$. Podobnie też jak u rosyjskiego formalisty chodzi Białoszewskiemu o dezautomatyzację, stwarzającą (to najpoważniej krytyczny, instytucjonalny aspekt jego działalności artystycznej) możliwość odmiennej konfiguracji elementów, które w regulujących naszą codzienność instytucjach przyzwyczailiśmy się traktować jako nienaruszalne. Pojawiająca się w 1951 roku w Kalejdoskopie wizja sztuki jawi się zatem tyleż jako „tradycyjna” czy „autonomiczna”, ile jako neoawangardowa, świadomie i różnicująco „po twarzająca" tradycję w kontekście skrajnie upolitycznionej sztuki socrealizmu ${ }^{88}$. Postać wiecznie zaśmiewającego się Boga, którego bez mała połowa wypowiedzi opatrzona jest didaskaliczną wskazówką „śmiech”, wydaje się z kolei policzkiem wymierzonym ówczesnej surowej teologii Kościoła katolickiego.

86 I. Kant, Krytyka władzy sądzenia, przeł. J. Gałecki, Warszawa 1986, s. 263, 107.

87 Na temat tytułu broszury Szkłowskiego i umieszczonego pod nim streszczenia jej treści, mówiącego o „wskrzeszeniu rzeczy”, zob. D. Ulicka, Przestrzenie teorii, „Białostockie Studia Literaturoznawcze" 2017, nr 11, s. 9.

88 Jeżeli Kalejdoskop uznać można za różnicujące powtórzenie eschatologiczno-historiozoficznych dramatów z Boska Komedia na czele, to napisany w podobnym czasie i podobnie bezpretensjonalnie poczynający sobie z postacią Boga i wizjami zaświatów „poemat sceniczny” Rozalie stanowiłby - jak w liście do Solińskiego pisał sam poeta przewrotną, niewczesną próbę „,zbliżenia teatru do dramatu liturgicznego” (XIII, 367). 
Nieobecność Sądu i towarzysząca jej niewiara w kres nie wydają się bynajmniej kalejdoskopowym ekscesem; mogą one dobrze tłumaczyć specyficznie deprecjonujący stosunek do śmierci, stanowiący podstawę wielu tekstów Białoszewskiego, słyszalny m.in. w słynnym, zwieńczonym wyrazem ulgi i pochwałą ,spokoju” Wywiadzie (X, 244) czy w dość częstych wyznaniach typu: „A już na pewno nie boję się umrzeć” (TD, 696). Szczególnie wyraźnie motyw zawieszenia wyroku pojawia się jednak w pochodzącym z Rachunku zachciankowego wierszu Po moim patronie, stanowiącym zarazem świetny przykład wykorzystania wzorców hagiograficznych i wymowną wypowiedź metapoetycką (jak słusznie twierdzi Elżbieta Winiecka, imię „Miron [...] staje się tu syllepsis umożliwiającą grę znaczeń" ${ }^{89}$ ). Oto skazany na śmierć przez ścięcie św. Miron męczennik mocą modlitwy w nieskończoność odwleka to, co nieuniknione:

Święty Miron klęka:

— czekaj

- o długo bo ja

- będę się modlił

— do końca świata

Świat się nie kończy.

Klęczy pod miecz

On Miron

jest

Swięty

Nad oprawcą cierpi

ale stać go na to

aż do końca świata

(I, 175-176)

„Stać go na to" - oto ekonomia zbawcza obu Mironów. Zarówno tego z Kizyku, jak i tego z Lizbońskiej stać na królewską pogardę wobec końca, dzięki której - miast lęku i niezależnie od życiowych przeciwności - może się pojawić czysta i niewinna, lecz bynajmniej nie naiwna i wbrew pozorom wcale nie pogańska radość życia, najwyraźniej dochodząca do głosu w głęboko przekornym Autoportrecie radosnym z Obrotów rzeczy. Wymowny ów wiersz należałoby przeczytać wreszcie jako tekst teologiczny - zwłaszcza że w dorobku poety poprzedza go obcy polskiemu katolicyzmowi obraz tańczącego Chrystusa: „Piękny Chryste,/ nie chodź, Mistrzu/ po swym Testamencie,/ tańcz tu z nami/ i z biodrami,/ bo masz piękne lędźwie!” (Rozalie, XIII, 283). Rygorystyczna nauka o odkupieniu przeciwstawiona została w Autoportre-

89 E. Winiecka, Białoszewski sylleptyczny, s. 71. 
cie... uderzającej swą prostotą zapowiedzi „pójdę do nieba”, uzwyklonej poprzedzającą ją frazą: „zwyczajem każdego kłębka” (I, 108). Nie przekreśla ona wszakże (na co wskazuje m.in. polisemia użytego czasownika „porwać”, odsyłającego również do frazeologizmu „porwać kogoś do tańca”) rozświetlającej tekst apologii „tańca radości” - i zaiste trudno zgodzić się z opinią Fazana, według którego jego „kresem (i celem) jest śmierć”, stanowiąca nieuchronne „dopełnienie losu poety-tancerza" ${ }^{90}$. Tekst wie lepiej: dopełnieniem losu poety-tancerza jest „radość nie do opisania”, w obliczu której wszelkie (św. i nie św.) pisma zwinąć się muszą - zwyczajem kłębka - w kropkę. Czy ostateczną? Bynajmniej. Z kropek tworzy wszak Białoszewski niekończący się wielokropek, którym wieńczy swój autoportret, a który - niczym sfera ze środkiem wszędzie, a obwodem nigdzie - wydaje się obrazować „,wszystko”:

A kiedy porwie się taniec, zwyczajem każdego kłębka, pójdę do nieba -

gdzie się nic nie czuje, gdzie od początku byłem, zanim byłem, gdzie już do końca będę, gdy nie będę, tam - radość nie do opisania.

To wszystko.

(I, 108)

Ciąg dalszy nastąpi; pisarz pism nie św. nie przestaje świadczyć o tym aż do końca.

\section{Bibliografia}

Barańczak S., Język poetycki Mirona Białoszewskiego, Wrocław 2016.

Białoszewski M., Tajny dziennik, Kraków 2012.

Białoszewski M., Utwory zebrane, t. I-XIV, Warszawa 1987-2018.

Bielik-Robson A., Od Natury do Historii. Efekt Lutra u Hegla, „Konteksty” 2018, nr 3. Bogalecki P., Szczęśliwe winy teolingwizmu. Polska poezja po roku 1968 w perspektywie postsekularnej, Kraków 2016.

Borkowska G., „Pędy, rytmy”: jeszcze o Białoszewskim, „Teksty Drugie” 1995, nr 5. Bürger P., Teoria awangardy, przeł. J. Kita-Huber, Kraków 2006.

90 J. Fazan, op.cit., s. 58. 
Burkot S., Miron Białoszewski, Warszawa 1992.

Derrida J., Freud i scena pisma [w:] idem, Pismo i różnica, tłum. K. Kłosiński, Warszawa 2004.

Drewnowski T., Próba scalenia. Obiegi-wzorce - style, Warszawa 1997.

Dybciak K., Trudne spotkanie. Literatura polska XX wieku wobec religii, Kraków 2005.

Falkowski J., ,, Pan Mozart, pan Bach, pani Reginka, ja”. Spotkania z ludźmi i kultura w twórczości Mirona Białoszewskiego, Warszawa 2015.

Falkowski S., Pokorny prorok (dwa chrześcijańskie wiersze Mirona Białoszewskiego), „Ruch Literacki” 1985, nr 5-6.

Fazan J., Ale ja nie Bóg. Kontemplacja i teatr $w$ dziele Mirona Białoszewskiego, Kraków 1998.

Foster H., Kto się boi awangardy? [w:] idem, Powrót Realnego. Awangarda u schyłku XX wieku, przeł. M. Borowski, M. Sugiera, Kraków 2012.

Gleń A., „, W tej latarni...”. Późna twórczość Mirona Białoszewskiego w perspektywie hermeneutycznej, Opole 2004.

Kant I., Krytyka władzy sądzenia, przeł. J. Gałecki, Warszawa 1986.

Karpowicz A., Kolaż. Awangardowy gest kreacji. Themerson, Buczkowski, Białoszewski, Warszawa 2007.

Kircher H., Człowiek-Miron. Zamiast wstępu [w:] Miron. Wspomnienia o poecie, oprac. H. Kircher, Warszawa 1996.

Kopciński J., Gramatyka i mistyka. Wprowadzenie w teatralna osobność Mirona Biatoszewskiego, Warszawa 1997.

Krajewska A., Białoszewskiego ,,dramat osobny”, czyli ,wypadek z genologii” [w:] Pisanie Białoszewskiego. Szkice, red. M. Głowiński, Z. Łapiński, Warszawa 1993.

Kunz T., ,„Ja: pole do przepisu”. Miron Białoszewski, czyli literatura jako forma istnienia, „Teksty Drugie” 2006, nr 5.

Kwiatkowski J., Abulia i liturgia [w:] idem, Klucze do wyobraźni, Warszawa 1964.

Marks K., Przyczynek do krytyki ekonomii politycznej, przeł. E. Lipiński, Warszawa 1953.

McClure J., Półwiary. Literatura postsekularna w czasach Pynchona i Morrison, przeł. T. Umerle, Kraków 2016.

Miłosz C., Dar nieprzyzwyczajenia. Nowy poeta polski, „Kultura” 1956, nr 10.

Miłosz C., Przeciw poezji niezrozumiałej, „Teksty Drugie” 1990, nr 5-6.

Niżyńska J., Królestwo małoznaczacości. Miron Białoszewski a trauma, codzienność i queer, przeł. A. Pokojska, Kraków 2018.

Nycz R., ,, Szare eminencje zachwytu”. Miejsce epifanii w poetyce Mirona Białoszewskiego [w:] Pisanie Białoszewskiego. Szkice, red. M. Głowiński, Z. Łapiński, Warszawa 1993.

Orska J., Nauka chodzenia. O tekstach programowych późnej awangardy [w:] Nauka chodzenia. Teksty programowe późnej awangardy, t. I, red. W. Browarny, P. Mackiewicz, J. Orska, Kraków 2018. 
Orska J., Życie jako happening. O artystyczności „, tajnego dziennika” Białoszewskiego [w:] Białoszewski przed „Dziennikiem”, red. W. Browarny, A. Poprawa, Kraków 2010.

Płuciennik J., „Będzie i będzie” Białoszewskiego? [w:] O wierszach Mirona Białoszewskiego. Szkice i interpretacje, red. J. Brzozowski, Łódź 1993.

Poprawa A., Mistrz duchowy w trafach społecznych [w:] Białoszewski przed „Dziennikiem”, red. W. Browarny, A. Poprawa, Kraków 2010.

Pustkowski H., Rodowód „Góry odosobnienia” [w:] idem, „Gramatyka poezji”?, Warszawa 1974.

Sandauer A., Poezja rupieci [w:] idem, Samobójstwo Mitrydatesa. Eseje, Warszawa 1968.

Sobolczyk P., Dyskursywizowanie Białoszewskiego, t. I-II, Gdańsk 2013-2014.

Sobolewska A., Maksymalnie udana egzystencja. Szkice o życiu i twórczości Mirona Białoszewskiego, Warszawa 1997.

Sobolewska A., Mapy duchowe współczesności. Co nam zostało z Nowej Ery?, Warszawa 2009.

Sobolewski T., Człowiek Miron, Kraków 2014.

Sobolewski T., Szaman [w:] Miron. Wspomnienia o poecie, oprac. H. Kircher, Warszawa 1996.

Stala M., Czy Białoszewski jest poeta metafizycznym? [w:] Pisanie Białoszewskiego. Szkice, red. M. Głowiński, Z. Łapiński, Warszawa 1993.

Stańczakowa J., Ocalić wszystko [w:] Pisanie Białoszewskiego. Szkice, red. M. Głowiński, Z. Łapiński, Warszawa 1993.

Śniecikowska B., Haiku po polsku. Genologia w perspektywie transkulturowej, Toruń 2016.

Świeściak A., Miron Białoszewski: alienacja i utopia. O neoawangardowych kontekstach poezji Białoszewskiego, „Poznańskie Studia Polonistyczne. Seria Literacka” 2014, nr 24.

Ulicka D., Przestrzenie teorii, „Białostockie Studia Literaturoznawcze” 2017, nr 11.

Winiecka E., Białoszewski sylleptyczny, Poznań 2006.

Winiecka E., Z wnętrza dystansu. Leśmian - Karpowicz - Białoszewski-Miłobędzka, Poznań 2012.

Woźniak T., I ty możesz zostać mistykiem. Zestaw ćwiczeń z dodaniem dziewięciu wierszy Mirona Białoszewskiego, „Teksty Drugie” 1996, nr 2-3.

Zagajewski A., W Warszawie jak na wsi [w:] idem, Drugi oddech, Kraków 1978. 